\title{
District Health Care
}


Other titles by G. J. Ebrahim include:

Breast Feeding: the Biological Option

Child Care in the Tropics

Child Health in a Changing Environment

Practical Mother and Child Health in Developing Countries

Handbook of Tropical Paediatrics

Paediatric Practice in Developing Countries

Maternal and Child Health Around the World (with Helen Wallace)

Care of the Newborn in Developing Countries

Nutrition in Mother and Child Health

The Authors and Publishers wish to thank CAFOD (The Catholic Fund for Overseas Development) for generously subsidising the paperback edition of this book. 


\section{District Health Care \\ Challenges for Planning, Organisation and Evaluation in Developing Countries}

R. Amonoo-Lartson

G. J. Ebrahim

H. J. Lovel

J. P. Ranken

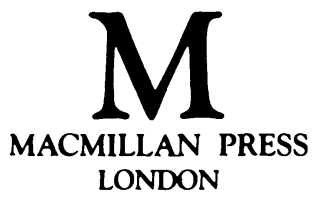


(C) R. Amonoo-Lartson, G. J. Ebrahim, H. J. Lovel, J. P. Ranken 1984

Softcover reprint of the hardcover 1st edition 1984 978-0-333-36600-4

All rights reserved. No part of this publication may be reproduced or transmitted, in any form or by any means, without permission.

First published 1984 by

THE MACMILLAN PRESS LTD

London and Basingstoke

Companies and representatives throughout the world.

ISBN 978-0-333-36601-1 ISBN 978-1-349-17515-4 (eBook)

DOI 10.1007/978-1-349-17515-4 


\section{Contents}

Preface $\quad$ ix

1 The Need for Management in District Health Care 1

Who is this book for? In what district? 1

Why is a new approach to health care needed? How have the old approaches failed? 4

Health services continue to grow yet health problems and health service inadequacies persist 4

Why no improvement in health? 9

Extra problems exacerbating the difficulties of health care $\begin{array}{ll}\text { planning } & 12\end{array}$

A new approach to health care and its management requirements 14

The origins of the new approach 14

Features of primary health care $\quad 14$

Management requirements for successful primary health care 15

Further Reading 25

2 Finding Out About Health Needs in the District 26

Who? What? Where? When? Why? in ill health 27

Which age groups contain most people and which age group is increasing fastest? $\quad 27$

Who gets sick? Who dies? 27

Who needs maternity care? $\quad 28$

What are the health problems? 29

Where are the health problems in the district? 33

When does ill-health occur? 36

Why does ill-health occur? 36

What is wrong with the existing health services?

Are the services coping? 41

Coverage $\quad 42$

Are people utilising the services? 43

Is the 'at-risk' concept being used in provision of health services? 44

Is there adequate quality of care? 
Is staff morale high? $\quad 46$

Do staff interact? $\quad 46$

Is there regular health services evaluation?

Identifying local resources 47

Who is providing health care? Who do people go to for advice?

Where? When? At what cost? 48

People other than health workers as resources $\quad 56$

Resources of material and labour $\quad 58$

Financial resources $\quad 59$

Natural resources $\quad 60$

Further Reading $\quad 65$

3 Making a Health Plan for the District 67

$\begin{array}{ll}\text { What is a plan? } & 67\end{array}$

The planning process $\quad 68$

The health planning and implementation cycle $\quad 68$

Dangers of planning and why planning sometimes fails $\quad 68$

$\begin{array}{ll}\text { Planning is a learning process } & 70\end{array}$

Key concepts in effective district health planning 72

Examples of different elements of a district health plan $\quad 86$

$\begin{array}{lr}\text { Further Reading } & 101\end{array}$

4 Building the Health Organisation in the District 102

$\begin{array}{ll}\text { Formal and informal organisation } & 102\end{array}$

An organisation as a skill pyramid 104

An organisation as a network of individuals 105

An organisation as a system or series of systems for getting things done 106

Some key principles in an effective organisation 109

The key elements of an effective organisation 113

What it means to manage a district health organisation $\quad 115$

Managing within the local socio-cultural environment 118

$\begin{array}{ll}\text { Further Reading } & 120\end{array}$

5 Practical Management: Putting Plans into Action 121

Management by objectives $\quad 121$

$\begin{array}{ll}\text { Standards } & 126\end{array}$

Personal skills of the manager 128

$\begin{array}{ll}\text { Managing time } & 128\end{array}$

Delegation 131

Teamwork $\quad 133$

Meetings $\quad 137$

Group Effectiveness Assessment 138 
$\begin{array}{ll}\text { Motivation } & 139\end{array}$

Communication 141

Management of change $\quad 145$

Introducing change 146

Recognising the need for change 147

Planning the change $\quad 147$

Implementing the change $\quad 147$

Checking and monitoring change 148

Checklist for organisational change 149

Managing conflicts 151

The problem-solving approach $\quad 152$

$\begin{array}{ll}\text { Bargaining } & 152\end{array}$

Use of 'third parties' 153

Avoiding or ignoring the conflict 153

Giving support to supervisors 153

The job of supervisors 154

Support for supervisors 155

Personnel - the management of health workers $\quad 155$

Recruitment and selection $\quad 156$

Induction and training $\quad 156$

Allocation work $\quad 156$

Supervision $\quad 156$

Discipline and grievance $\quad 156$

Good communications $\quad 156$

Counselling and guidance 156

Promotion and career development 156

Manpower planning $\quad 157$

Training 158

Staff development $\quad 159$

$\begin{array}{ll}\text { Maintaining standards and discipline } & 162\end{array}$

Disciplinary rules 163

A disciplinary procedure 163

Counselling - or helping staff with their problems $\quad 164$

$\begin{array}{ll}\text { Finance } & 165\end{array}$

Sources of finance 165

$\begin{array}{ll}\text { Operating budgets } & 167\end{array}$

Costing information $\quad 168$

$\begin{array}{lr}\text { Financial reports } & 169\end{array}$

Buildings $\quad 169$

Supplies and stores $\quad 171$

Drugs, vaccines and other pharmaceuticals 173

Vaccines 174

$\begin{array}{ll}\text { Transport } & 175\end{array}$

$\begin{array}{ll}\text { Further Reading } & 176\end{array}$ 
6 Getting Feedback: Monitoring and Evaluation 178

Why do we need feedback? 178

What should be evaluated? 180

What needs to be evaluated depends on the community diagnosis of problems and resources

What needs to be evaluated depends on the plan of action for the health team in the district

What are the key components of evaluation which often get neglected?

What are the essential elements of primary health care which need to be evaluated?

Which level? Which component? - levels of evaluation 184

$\begin{array}{ll}\text { What level of feedback and which component in a programme? } & 184\end{array}$

Which specific questions can feedback from a health care programme consider?

How can data be obtained to find out what is going on?

Quick or long? and what disciplines in getting feedback on a programme?

Examples of data collection forms and systems used in local communities

Choice of evaluation method

Experiment design

188

Quasi-experimental design $\quad 188$

Patient care evaluation

Who is to obtain the feedback information 193

Where should the feedback be done? 195

When should feedback information be obtained? 195

Constraints on getting feedback 195

Further Reading 195

7 Future Prospects: Challenges for Change 196

Management issues likely to arise during the next decade $\quad 198$

Obstacles and constraints 200

Opportunities for further growth 201

The untapped resources 203

Beyond primary health care? 204

$\begin{array}{ll}\text { Index } & 205\end{array}$ 


\section{Preface}

In 1961 when I was involved with other colleagues at the Ministry of Health in Tanzania in planning the mother and child health services, we knew very little about management and planning. There was also not much help available from the existing medical literature at the time. All we had was the objective of making basic health care available to the vulnerable groups who together made up two-thirds of Tanzania's population. More than 90 per cent of the country's population was rural, living in widely dispersed homesteads or scattered family groups. There were no models of health care planning which we could follow. Besides there was the growing doubt that many of the modern approaches and concepts in health care had evolved out of the experiences of the Western industrial societies which are predominantly urban and have access to far greater resources than any developing country can ever muster. How relevant would the Western systems of health care be for Tanzania's health problems? Independent Tanzania with a highly committed leadership required basic health care to reach out to all its people, however remotely situated and whatever their social status. A start was made in which all available health resources came to be mobilised with a growing reliance on medical auxiliaries and paramedical personnel. Inevitably many mistakes were made, but they also provided the much-needed learning experience.

For many years it had been my wish to describe the lessons learned from my Tanzanian experience. I knew I lacked the breadth of experience necessary for such a task even though my travels with the WHO/UNICEF-sponsored course, for senior teachers of child health, gave me the opportunity to study the health services of several countries. When Hermione Lovel joined the Tropical Child Health Unit, the idea of this book began to develop further. She had completed a study for Ghana entitled 'Future steps towards a Primary Health Care Strategy for Ghana' and a major part of this book is based on her experience of Ghana's health care problems.

During the period when Hermione Lovel was conducting her enquiry into Ghana's health systems, Dr Amonoo-Lartson was the Chairman of the Primary Health Care sub-committee of the Health Manpower Committee. His special area of interest is management in health. During the period 1977-81 when he was deputy director of Medical Services in Ghana he carried responsibility for the management of the hospital services, including the co- 
ordination of church-related hospitals with the national health system. He had also been involved in the evaluation of several development projects in Ghana and knew that for Primary Care to succeed, close relationships and support with hospital services were essential. It is not a question of 'either/or', but that both types of health care working together in harmony is essential. Such harmonious relationships require good management.

When John Ranken joined the Tropical Child Health Unit he brought with him not only expertise in management but also the experience of teaching the subject to members of the health and nursing professions. We knew that the four of us could pool our experiences to compile a text for colleagues working in remote areas of the developing world with no access to literature or professional managerial advice.

The book is less than half the size of the material originally compiled by us. There are several topics which need lengthier discussion and several other topics which had to be left out. Considerations of cost have imposed restrictions on the size of the book. However, the cost of the paperback version of the present edition has been kept low because of a generous printing subsidy from CAFOD (The Catholic Fund for Overseas Development) to whom the authors are indebted. In the meantime we would depend on our readers for suggestions and advice concerning future changes. 